\title{
THE HOTTENTOT VENUS, FREAK SHOWS AND THE NEO-VICTORIAN: REWRITING THE IDENTITY OF THE SEXUAL BLACK BODY
}

\author{
Maria Isabel Romero Ruiz, University of Málaga (Spain) ${ }^{1}$ \\ Email: mirr@uma.es
}

\begin{abstract}
The Hottentot Venus was an icon of primitive sexuality and ugliness, but also the victim of commodification and sexual exploitation in the freak shows of the nineteenth century. Similarly, she was the object of medical observation at a time when blackness and otherness were connected with human inferiority. Chase-Riboud wants to contest these notions in her novel The Venus Hottentot (2003) and to retell the story of Sarah Baartman, following the Neo-Victorian trend of rewriting the past and giving voice to the marginalised. She also highlights the presence of these colonial traces of the past in our postcolonial present and claims agency and beauty for black women.
\end{abstract}

Key words: black female body, colonisation, commodification, deviant sexuality, freak show, Neo-Victorian, Venus Hottentot.

Título en español: "La Venus Hottentot, los circos y el Neo-victorianismo: reescritura de la identidad sexual del cuerpo negro"

Resumen: La Venus Hottentot fue un icono de la sexualidad primitiva y de la fealdad, pero también fue víctima de la cosificación y la explotación sexual en los espectáculos circenses del siglo XIX. Asimismo, fue objeto de observación médica en una época en la que la negritud y la otredad eran relacionadas con la inferioridad humana. Chase-Riboud cuestiona todas estas nociones en su novela The Venus Hottentot (2003) y cuenta la historia de Sarah Baartman, siguiendo la tendencia Neo-victoriana de reescribir el pasado y dar voz a los marginados. También enfatiza la presencia del pasado en nuestro presente postcolonial y reclama agencialidad y belleza para las mujeres negras.

Palabras clave: cuerpo femenino de color, colonización, cosificación, sexualidad desviada, circos, Neo-victoriano, Venus Hottentot.

\section{INTRODUCTION ${ }^{2}$}

The Hottentot Venus has become an icon of the commodification of the female black body that has important connotations for scholarly research and constitutes a precedent for the exploitation of female black sexuality. The tour around Europe of Sarah Baartman - or Saartjie Baartman, her Dutch name-- during the nineteenth century and the discussions

\footnotetext{
1 Date of reception: 10 june 2013

Date of Acceptance: 6 November 2013

2 The author wishes to acknowledge the funding provided by the Spanish Ministry of Science and Research for the writing of this article (Research Project FEM2010-18142).
} 
that the prodigious size of her back and genitals provoked called the attention both of a male and a female middle-class audience, especially in the freak shows of London and Paris. As a consequence, she became the embodiment of black racialised sexuality and the object of observation and study on the part of the Western scientific world. She became a symbol of deviant sexuality that attracted the white European gaze. White men felt lured by the "exotic" and "the other", and, in the same fashion, women felt attracted by the far too uncommon appearance of a woman of colour in comparison with the western civilised standards. A victim of slavery, she never left her status as a bonded woman, providing her male and female audience with the spectacle of the primitive.

In her novel, The Hottentot Venus, published in 2003, Barbara Chase-Riboud tries to bring to light the story of a woman whose life represents the utmost vilification of the female black body and sexuality. Under the Neo-Victorian genre, she tries to question issues of sexual exploitation and discrimination and to re-write the history of slave-women giving a voice to the victims. The experience and the memory of slavery constitute a key element in the reconstruction of the past and in the construction of a better future. Also, she resorts to spectrality to give her protagonist some agency.

Therefore, this article seeks to examine issues of black female identity and sexual deviancy based on women's bodies and sexualities which connect the postcolonial perspective and the Neo-Victorian approach with the history of slavery and sexual exploitation and commodification of black women.

\section{HISTORIOGRAPHIC METAFICTION, FREAK SHOWS AND NARRATIVES OF SLAVERY}

The Hottentot Venus can be read as a neo-slave narrative situated in the context of the Neo-Victorian fiction in a wide encompassing sense. The fact that Neo-Victorian novels are historical fictions which re-write, re-possess and interpret the past is perceivably relevant to Chase-Riboud's story. Also the idea that these texts give voice to the marginalised, the silent and the deviant has many points of coincidence with the postcolonial and the reformulation of "otherness" and its consequences for the present. The Neo-Victorian genre is similarly particularly concerned with issues of entertainment and ethnographic exhibition and with the scientific and medical discourses that determined the observation and interpretation of the racialised body in the nineteenth century.

According to Linda Hutcheon, these Neo-Victorian texts belong to the genre of historiographic metafiction, which consists in giving a new form to the archive under the light of contemporary issues and concerns, trying to satisfy our desire to know the Victorian reality (2002: 67-88). Writers and readers share their interest in the past, as well as their unease about that past and its implications for the present. Both history and fiction are artificial constructs, so their veracity can be questioned and reshaped. Therefore, historical fiction can be interpreted as the quintessential form of Postmodernism and the postmodern culture (Heilmann and Llewellyn 2004: 139-141). Thus, Neo-Victorian writers "are not merely looking back, but using their appropriation of form, style and theme to make some kind of intervention in our understanding of the Victorian period", projecting an image that probably Victorians did not have of themselves or could not express because of the social and 
literary limitations of the period (Preston 2008: 99). At this point, I am very interested in the hermeneutics of the narrative, as Mark Llewellyn points out, because there is an individual interpretation of every literary text, but there exists also an individual interpretation of history, so that the aesthetic choices of writer and readers are not always coincident (2009: 32). This does not imply that the text lacks authenticity in a realist sense because NeoVictorian writers base their use of history on research, but the boundaries between fact and fiction are blurred, and we can find many instances of this in the novel object of my discussion. There is for example some historical vagueness regarding some aspects of Sarah Baartman's life and some relevant events as well, to which I will refer later in the text. In the same fashion, real historical characters appear in Neo-Victorian narratives together with well-known writers (Llewellyn 2009: 38). In this manner, Napoleon, Darwin, Cuvier, Jane Austen, the actor Henry Taylor, Mr. Bullock -the owner of the Liverpool Museum, known as the Egyptian Hall in London-and Henri de Blainville, become real protagonists of the story, and many other historical characters and famous writers become examples of the intertextuality that characterises Neo-Victorian fiction. Most chapters begin with a quotation from one of the many treatises that Baron Georges Léopold Cuvier wrote on anatomy and other medical sciences and the four parts of the book are introduced with a quotation from famous European writers such as Mary Shelley, Gustave Flaubert, George Eliot, Joseph Conrad and Alexander Pushkin. The first person narrative, when it happens, tries to give voice to the protagonist, Sarah Baartman, following the Neo-Victorian trend of recovering the utterances of those neglected by history, but in a fragmented way, as the narrator keeps changing throughout the story and other characters take the role of relating the events.

The Neo-Victorian genre thereby connects with issues that were prominent in the nineteenth century debates and that have an echo in the controversies of the late twentieth and early twenty-first centuries, with topics of discussion such as "environmental and genetic conditioning; previously oppressed and repressed sexualities; crime and violence; urban development; the history and consequences of colonialism and post-colonialism; and the conflict between science and religion" (Preston 2008: 106). In this context, the Venus Hottentot's story is especially relevant for the re-writing and revision through remembrance of the colonial past of slavery and its consequences for our postcolonial present. The experience of being "the other" has a prominent importance and significant political implications as far as women and ethnic writers are concerned. Reclaiming black women's identities and bodies is one of the main aims in the feminist agenda of our contemporary societies, and to obtain agency by looking back to see the past with new eyes and re-write that past outside the white male tradition is the fundamental objective of historical novels written by women of colour (Heilmann and Llewellyn 2004: 142).

Sarah Baartman defines herself and her companions in the world of freak shows as "things-that-should-never-have-been-born"; the taste of the English for freak shows and other public entertainment is stated in the definition of show business as "the art of catering to the slenderly learned and common sort. It is the same as accounts of murders, executions, witchcraft and other prodigies. The English are a nation of starers and they have a taste for monsters that cuts across all classes" (Chase-Riboud 2003: 177). Although Sarah's story in connection with public exhibition starts in 1810 and lasts till her death in 1815, the freak show as the spectacle of bodily difference reached its climax between 1847 
and 1914 in England and the rest of Europe. Before that, words like "monsters", "human oddities", "lusus naturae", "prodigies" or "novelties" were familiar to English and European audiences. However, these shows were not only "marginal, exploitative, or voyeuristic forms of entertainment" but also became "critical sites for popular and professional debates about the meanings attached to bodily difference", as we shall see (Durbach 2010: 1). Also, freak shows became an international institution not only displaying people with more than two hands, arms, legs, or feet, Siamese twins, dwarfs, bearded women, fat women and so on, but also human oddities from around the world, especially with the expansion of the British Empire and the process of colonization. This mixture of exhibits shows the cultural anxieties and fear of miscegenation that characterised English and European nineteenth century societies. These fears and anxieties were closely linked to scientific discourses that aimed to establish what it meant to be white, British and European in contrast with uncivilised, colonised people, and to assert the moral and intellectual superiority of the colonisers (Durbach 2010: 3-4).

Freakery was a common profession in the Victorian period. Freaks considered themselves professionals who had their own techniques regarding costumes, choreography, music and songs, stage machinery and supporting materials like souvenirs and pamphlets. Their spectacles were advertised in the press of the day and the merchandising of their image made of them a profitable business. In this sense it is important to bear in mind that they did not consider themselves "disabled" in the modern sense of the word. ${ }^{3}$ Therefore, freaks were able-bodied people who could work and did not have to resort to public charity, thus keeping their respectable status; they even had contracts and managers (Durbach 2010: 18-19). Chase-Riboud herself emphasises the normalcy of freaks by describing their lives outside performances as the same as those of the rest of the population, although she talks about three types of these individuals: natural-born freaks, made freaks and fake freaks (2003: 177). They talked, drank, ate or loved as the rest of the people.

Sarah Baartman was bound by a contract to exhibit her body in Europe, first in London and then in Paris. She left Cape Town after having lost all her family: her parents, her husband and her child -according to her biographers she had several children-, who had been the victims of different massacres by British and Dutch white colonisers. ${ }^{4}$ She had a number of masters being an indentured servant, but Chase-Riboud only mentions the two black brothers, Peter and Hendrick Caesar -Cesars in the archive-, the naval surgeon

\footnotetext{
The English Poor Law of 1834 introduced the categories of the "able-bodied", those who could work, and that of "the infirm", those who could not work because of old age and illness. The latter could only receive relief in the workhouse as the new law that was passed to substitute the Elizabethan Poor Law of 1601 suppressed "outdoor relief", making this public institution a most dreaded alternative to poverty.

4 A few years before the exhibition of the Venus Hottentot in London, the British Empire had expanded to South Africa in 1795, but the Dutch recovered it in 1803 to finally lose it again to the English in 1806 . The British colonised the Cape of Good Hope and they imposed their rule on both the Dutch and the Khoisan; the first were sent to the hinterlands, and the Khoisan maintained their right to work and live in the Cape. Nonetheless, they had few political and property rights, especially the Khoisan women who were subject to sexual and domestic exploitation. (Smith McKoy, 2011: 89) Under the Dutch rule the situation was not much better for the Khoikhoi people, so Sarah must have left the Cape for Europe with the hope of a better life with the slavery trade abolished in England.
} 
Alexander Dunlop, the actor Henry Taylor ${ }^{5}$ and the animal trainer Sieur Réaux. It calls the reader's attention the fact that two of her owners were black themselves, but at that time free blacks could have servants in South Africa. Also the Reverend Freehouseland and the naturalist Georges Cuvier had a very important role in her life as a maid and in her death as a specimen that represented female deviancy. However, the Reverend freed her, and one of the reasons why she wanted to go to England was to visit his tomb in Manchester, according to the novel. Still, she kept her loyalty to the Caesars and especially to Dunlop who had offered her a promise of marriage, and followed her Khoekhoe traditions which established "a very strict code of behaviour and a code of honour that was relentless"; to this was added "the admonishments of the Wesleyan mission with all its Thou Shalt Nots" (Chase-Riboud 2003: 19). The power and influence of the missions on native South African people is made evident here, but it is the marriage contract with Dunlop that makes her earn the money for her dowry in the freak shows of Europe.

The fact that the English government was very much involved in the issue of contracts and wanted to check the willingness on the part of the performers is made evident in the novel in connection with the abolition of the slave trade in 1807 and of slavery itself in 1833. It was very important to safeguard the rights of those entertainers who were very far away from their places of origin, did not speak the language of the country and did not have family or friends to resort to in times of need and difficulties (Durbach 2010: 12-13). For example, Sarah's illiteracy is referred to very often in the novel. She says that "books don't talk to black people", meaning that she cannot read or write, although she eventually learns, regaining some control over her mind and body. There was an official preoccupation about slave trade and its abuses. Thus, in the narrative, Dunlop and Caesar are taken to court on charges of "sequestration and kidnapping, dealing in contraband, affront to public decency, and assault and battery". (Chase-Riboud 2003: 129). In the narrative, it is the African Association in the figure of Reverend Robert Wedderburn that was behind this legal process. There were many black people living and working in England at the time, and this Association was founded to defend the rights of the slaves freeing and repatriating them when they had been victims of the trade. The allegations were based on the premise that the Governor of Cape Town -Lord Calledon- had not allowed the expatriation of the Hottentot and the Court of Chancery wanted proof that she had consented to the commercial transaction. For that, a contract had to be produced that bound Sarah from 1810 to 1816 both to Caesar and Dunlop, as a domestic servant in the case of the former and as a prospective husband in the case of the latter. However, she did not trust Wedderburn and saw his actions as another attempt at appropriation as she had been indoctrinated in resistance to the abolitionist cause and found it strange that a "white black man" was implicated in the fight. She therefore failed to recognise their common experience of racial exploitation (Heilmann and Llewellyn 2010: 126).

Yet, the marriage contract is also used by Chase-Riboud to demonstrate that the Khoesan people belonged to a more civilised society than the English, especially as far as women's rights were concerned:

\footnotetext{
Some biographers like Crais Clifton and Pamela Scully identify Alexander Dunlop and Henry Taylor as the same person, but they are differentiated in the novel.
} 
[...] young people could choose to live with one another without a contract of marriage. The couple could at any time dissolve the union or sanctify it with the banns of matrimony. However, once the banns had been posted and approved by the elders, no other man could intrude on a husband's rights by contract (Chase-Riboud 2003: 24).

This establishes a clear contrast with the English law concerning marriage which reduces the status of women to something even inferior to that of a slave. Here the writer joins the cause of late eighteenth and nineteenth century feminist campaigns for reform of the marital contract which established that women were the property of their husbands together with their income and children (Heilmann and Llewellyn 2010: 126). Although in the novel she eventually marries Dunlop after having been baptised in the Church of England, according to her biographers, there is no evidence of the ceremony but there is a baptismal certificate of Sarah dated December 1811 in Manchester (Holmes 2007: 114-115).

This is the atmosphere in which she arrived in England in the Spring of 1810 (September 1810 in the novel). Caesar and Dunlop took lodgings in York Street, off St. James's Square, in the area of Picadilly, the epicentre of artists and showmanship:

There were plenty of amusements in the city: opera houses, theatres, circuses, gaming houses and casinos, puppet shows and dance halls, Chinese shadow plays, opium dens, and fairs of every kind. More importantly for us: there were dozens and dozens of public exhibition halls, none more prestigious or beautiful than that of the Liverpool Museum at 22, Picadilly, known as Egyptian Hall, owned by the illustrious William Bullock (ChaseRiboud 2003: 90).

Bullock himself was a naturalist and a traveller and a member of several learned societies, and he was addressed by Dunlop who wished to sell him the skin of a giraffe and to offer him his Hottentot woman to be displayed in his museum. Museums and exhibition halls became a prominent feature of British culture in the nineteenth century. Both animals and "exotic peoples as emblems of imperial conquest" invaded London public space and became an attraction that proved to be really lucrative for those in the business (Heilmann and Llewellyn 2010: 123). However, Bullock accepted the giraffe skin but he refused to accept the two-year contract for the Hottentot woman on the grounds that he could not exhibit a live human being in an animal museum. He considered himself "a museum director" and "not the keeper of a freak show" (Holmes 2007: 57-59). So, with the money from the sale of the giraffe skin, Dunlop and Caesar decided to rent a venue near the Liverpool Museum at 225, Piccadilly, attracting the crowds from there. The price of the ticket was two shillings, and they advertised her first performance in the Morning Herald and the Morning Post. To give publicity to their exhibition, Dunlop and Caesar made Sarah take regular rides in carriages on Sundays in the area of central London and soon members of the metropolitan aristocracy would hire her to entertain guests at dinners and private parties. She also gave "exclusive evening private views, restricted to parties of twelve" and they had to be booked "twenty-four hours in advance" (Holmes 2007: 68). The show was a success and she became famous all over London; crowds flocked to see her and she was the main feature of numerous songs, poems, penny posters, cartoons and newspaper articles, and some of them are reproduced in the text. Sarah herself mentions in 
the novel things like "Hottentot Venus soap", "Hottentot Venus bleach", "Hottentot Venus chocolates", "Hottentot Venus pastry", "Hottentot Venus coffee", "Hottentot Venus tea", "Hottentot Venus corsets", "Hottentot Venus rouge", "Hottentot Venus cigars" and "Hottentot Venus gunpowder". In her own words, "Hottentot was the name for everything crude, ugly, inferior, savage or simple-minded" (Chase-Riboud 20013: 155). She emerged as a painful example of the commodification of the black female body, which not only functioned as an icon of black sexuality in the European colonial imaginary, but also as the representation of irreducible racial difference (Henderson, 2003: 127). Her personification of the exotic freak playing on her exaggerated black sexuality made the discourses of science, ethnography and imperialism conflate and made her the object of consumption for English and French audiences alike: it was the spectacle of "the Other".

In the case of Sarah Baartman, most of the characteristics of the freak shows described above were implemented in her public persona and in her staging of primitiveness. Her apparel was designed to reinforce her image as a savage woman and as a sexually deviant. She talks herself of her

[...] being exhibited in an eight-by-twelve-foot bamboo cage just high enough for me to stand and almost naked, shivering in my apron of pearls and feathers, my leggings of dried entrails, my painted face, my leather mask, my dyed and braided hair, my doeskin red gloves, my sheep skin lappa slung over one shoulder, my necklace of shivering glass and shells, my crown of feathers, my cowrie seed earrings, able to stagger only a few paces, or crouch over my brick kiln for warmth, or obey the shouts of my keeper (ChaseRiboud 2003: 4).

Her animal-like display and her props were specifically designed to attract an audience who wanted to see the spectacle of the exotic. Many of these things were probably generated by her master's trips, but it was important to create the illusion of semi-nakedness to highlight her uncommon buttocks in the eyes of English men and women. For that she wore a costume "arranged in composite layers over her fleshings, a tailor-made one-piece body-stocking, or leotard, fashioned from a figure-hugging fabric of silk and cotton" (Holmes 2002: 6364). The adornment she wore was fabricated to cover her pubis and the hanging pieces it had were elaborated to hide her famous "Hottentot apron" or elongated labia typical of her civilization. She also used grease paint, kohl, powder, combs and oil to make up her face and do her hair. The meaning of the mask she wore is not clear; according to some critics and historians, this mask gave her a degree of agency, hiding her identity behind it, and having the possibility of subverting the gaze and even returning it. It called the spectator's attention on the one hand, but it denied access to her real persona on the other (Heilmann and Llewellyn 2010: 115-116). In my opinion, it was probably just part of her staging of the Khoekhoe woman and the image her master pretended to transmit to her audience.

The stage was also ready for her representation: African pastoral landscapes and flora formed the background and the illumination was provided by torches, candles and oil lamps. The performance was accompanied by music and dance, and Sarah emerged from her hut at Caesar's command. The instrument she played was called a ramkie, an African guitar which comprised six hundred years of South African history and with influences from Portugal and the East connected with colonisation and slavery. The music it produced was 
an antecedent of the blues, and Sarah sang popular Khoi, Afrikaans and English songs and danced to their tunes (Holmes 2007: 63, 66-67). The audience was familiar with some of them, but Chase-Riboud points out that their behaviour made an impression on Sarah who was frightened as she described her performance:

My heart accelerated and my breathing became shallow. The crowd was like hounds at bay, snickering and howling insults, chewing tobacco, spitting and coughing. Even without looking around, I knew I would see that particular lurid stare of pure folly with which people contemplated black skin (Chase-Riboud 2003: 112).

In many cases, freaks interacted with their audiences, speaking to them in different languages -Sarah spoke English, German and her own native language-and letting them even touch or examine them. There are many instances in the story where Chase-Riboud mocks the English audiences and compares their behaviour to that of the animals and the uncivilised, establishing a contrast with the supposed civilisation of these white observers. This is the potential of the Neo-Victorian genre, as it allows the readers to question the past and to analyse its implications for the present. In this particular case the author tries to challenge the view that white Europeans are more civilised than African blacks, and to determine if the equation between Hottentot and animal/inhuman has a solid ground in the Western thought. This is the main reason why Sarah becomes an alcoholic and a drug addict -she drinks gin and frequently smokes a pipe of dagga or what we know as cannabis- to be able to bear the humiliation and degradation she suffers as a subhuman symbol of sex; also to be able to work longer hours every time and to suffer her maltreatment as a servant and ethnographic exhibition.

Finally, freak shows were mobile spectacles that could be found not only in the big cities but also in the small towns and villages of Great Britain. When the London season was over, different forms of entertainment travelled throughout the country following the routes of fairs and wakes, which dated back to the Middle-Ages (Durbach 2010: 5-6). In the Spring of 1811, Sarah Baartman's tour of England and Ireland was initiated with bookings for Bath, Maidstone, Dublin, Leicester, Birmingham, Liverpool, Nottingham and Manchester, and by this time the actor Henry Taylor owned half of the business (Chase-Riboud 2003: 167). They travelled using a caravan, a covered wagon and a coach with canvas announcing the Venus Hottentot's show. And most importantly, freak shows in general, and Sarah's spectacle in particular, were presented as public entertainment not only for men of the middle-classes, but also for members of the working-class. Especially in the provinces, these performances were cheap, costing sometimes only a penny; there were also discounts for servants and factory workers, attracting an audience from a wide social range. Similarly, freak shows were presented as decent leisure activities, attracting a number of middle-class women who began to occupy certain spaces in the public arena. To exploit this potential, freak show entrepreneurs offered views only for them and even offered tickets for children at half-price (Durbach 2010: 6-7).

The presence of women in freak shows and ethnographic spectacles was connected with the attraction that both genders felt for the naked bodies of black slaves which fulfilled an erotic culture that dominated nineteenth century England and France (Gordon-Chipembere 
2011: 87). In this context, Sarah Baartman, the Hottentot Venus, became and icon of hypersexualised racial difference thanks to her two main body features: her Hottentot apron and her steatopygia or the prodigious size of her buttocks and hips.

\section{SCIENTIFIC DISCOURSE, FEMALE DEVIANCY, AND BLACK WOMEN'S SE- XUAL IDENTITY}

London had a population of between five and ten thousand blacks, predominantly male, so the presence of a female Hottentot represented a prodigy which attracted the interest of both white men and women alike (Crais \& Scully 2009: 67). To this, we should add the fact that Georgian England was fascinated with buttocks of all forms and sizes that were present in pornography and prostitution, especially if the were big. They were the object of metaphors, jokes and puns and became a cultural icon of the time (Holmes 2007: 68-69). These features of Sarah's body and her sexuality, however, were rooted in ancestral Khoe Khoe traditions that, once again, bear witness to the civilised nature of South-African people commonly associated with the primitive by Europeans. Khoisan brides were prepared for marriage cultivating some physical traits which were more important than virginity itself and made them most valuable: they had tiny waists which accentuated their "sumptuous, mountainous hips". For that, their bottom parts were "massaged with butter and secret swelling ointments" and they were fed with "peanuts oils and corn porridge and honey" so that their thighs could become more fleshy above the knees. But the ultimate symbol of their femininity was the size of their sex where resided the most important part of their beauty; it was kept hidden by an elaborate beaded apron and it was designed to produce extreme pleasure in husbands. Sarah herself describes the process carried out by her aunt, as she was an orphan:

Aunt Auni made two incisions on each side so that the flesh curved downwards and placed a small pebble within. As the stones stretched the delicate membranes, she would insert a larger, heavier pebble until the flesh had descended to the length she desired and found beautiful. [...] Each month the pebble got heavier and my bride-price increased (Chase-Riboud 2003: 22).

This is the reason why those who possess her as a commodity in the home or the entertainment and scientific market want to possess her sexuality. In the novel, Peter Caesar obliges her to practice fellatio on him and she is raped by her brother Hendrick; also Cuvier feels a sexual attraction for her and abuses her. All of them want to experiment the rapture of the Hottentot apron and exert the power of the coloniser over the female black body. And this process is inextricably linked with the notion of flesh and the captive body of colonialism; thus, the captive body becomes "the source of an irresistible, destructive sensuality" which reduces it to a thing, therefore lacking a subject position and leading to an expression of "otherness". Black bodies become powerless and transform into flesh, concentrating ethnicity and desire, despite their being ugly (Spillers 1987: 67). The female black body represents the quintessential slave and its possession and control meant conquest for the white imperial master. This control was exerted through physical violence and rape, 
subordinating black women, depriving them of their identity and agency, and establishing a gender and race hierarchy (Hill Collins 1991: 166-167). Also, the infatuation that Europeans felt for Sarah Baartman's body was related to the "sexual fetishes that were excited by her buttocks, her breasts, and her labia" that led to her public commodification (Smith McKoy 2011: 91). The market economy in the nineteenth century thrived with sexual difference and depended on the production of desire, the same as nowadays. Sexuality is culturally mediated and dependent upon specific historical and social processes and, as a consequence, there is a correlation between commodities, consuming desires and sexual practices. Thus the notion of "fetishism" is based on the idea of the existence of natural versus unnatural needs, and the Venus Hottentot excited those prohibited desires that pure white women could not offer (Curtis 2004: 95). The fetishization of the black female body is further associated historically with the antebellum slave markets and the auction block where the black skin was commodified. In the same fashion, the "black bottom" has traditionally represented black femininity and racialised sexuality in the Western imaginary, and this is the reading we can make of Sarah Baartam's ethnographic exhibition. She symbolised deviant primitive sexuality in life and in death, with the dissection of her famous Hottentot apron or elongated genitalia (Henderson 2011: 132-133).

In nineteenth century Europe beauty was associated with the white female body, and blackness was associated with ugliness. There were two prevalent images of the black woman: on the one hand, female black bodies were strong productive and reproductive bodies, so they were able bodies in the labour market; but, on the other hand, they were dark-skinned, grotesque and anatomically excessive bodies that represented deviancy. In contrast, the white female body signified purity and weakness (Hobson 2005: 12). By the same token, the black female body elicited feelings of desire and disgust, producing the two existing tropes of female black sexuality: the Black Venus and the Savage Hottentot. Since the Venus Hottentot was a combination of the two, she simultaneously conjured up love and desire, savagery and primitiveness. She was the icon of exotic black femininity, and bestiality and unbridled sexuality. She simultaneously represented the "Jezebel" or the "mammy" and "Sapphire" or the "welfare queen" (Hobson 2005: 14). In Sarah's own words, "everything that was ugly, savage, uncivilised, brutal, deformed, reprehensible was called Hottentot, my name" (Chase-Riboud 2003: 6). In the case of white women, it was the prostitute that became the embodiment of the "essential sexualised female"; hence, she was identified with passion and disease. Therefore it comes as no surprise that all these arguments led to the identification of the black woman's and the prostitute's sexual identities in the iconography and social perception of these two female figures (Gilman 1985: 206, 221). This is the way in which Sarah Baartman is perceived by her masters, as when Dunlop talks about her as “... a monster of sex and provocation, an insatiable siren! A heartless, shameless savage... a superstitious man-eating, dirt-eating heathen..."; he even continues to say that "There is no difference between a Hottentot and a prostitute" and, consequently, "there is no moral deterrent to using one as the other". For him, in contrast with the prostitute, she is beyond redemption (Chase-Riboud 2003: 97).

In Chase-Riboud's story, after the British tour, Caesar and Dunlop lost the property of Sarah to a French bear tamer whose name was Réaux. He joined them during their trip around the country, and in 1814 they and the rest of the troupe travelled to France to try 
their luck in the Parisian world of show business. ${ }^{6}$ In those days slavery was not abolished in that land and they took lodgings at 15 Rue des Petits-Champs and ran their exhibition hall at 188, rue St. Honoré, in the Palais Royal area. Paris, the same as London, was a city where a variety of spectacles such as panoramas, cosmoramas, mechanical demonstrations, séances and illusions proliferated, and when Sarah arrived in this place her attitude changed. According to her biographers, she became "overwhelmingly amiable and ebullient on stage", captivating both French audiences and critics (Holmes 2007: 124). She was again an immediate commercial success. However, to make ends meet due to their difficult economic situation, from the initial six hours, she ended up working ten hours a day to make more profit through her performances, private views, visits to cafes and restaurants and attendance at parties and balls. This extra work load together with her abuse of drugs and alcohol to stand the long hours and the humiliation of being continuously exposed to the degrading observation of Western voyeurs led her to severe illness and a premature death. With a new owner and husband, master Réaux, after Caesar's departure for the Cape, they moved lodgings to 7, Cour des Fontaines, and also took another venue for the Hottentot exhibition on rue Montesquieu. At this stage, Sarah had to work twelve hours a day.

The exhibition of Sarah Baartman in England and France at the beginning of the nineteenth century is associated with several issues that characterised the age concerning white superiority and theories of normalcy and deviancy, the latter being ascribed to the inferior races. The eighteenth and the nineteenth centuries were, according to Foucault, periods in history when the classification and surveillance of individuals began to dominate the scientific and the medical discourses. To these we have to add the racial, sexual and colonial discourses, which established the inescapability of the objectifying gaze and the textual inscriptions of the Hottentot Venus. In his Discipline and Punish (1975) he states that individuals and their bodies are disciplined through discourses of power based on observation and punishment in institutions like hospitals, prisons, asylums, workhouses, schools, etc. Similarly, in the first volume of the History of Sexuality (1976), Foucault establishes that power is exerted by social relations connected with knowledge that allow the classification and definition of people based on binary codes like black/white, civilised/uncivilised, normalcy/deviancy, male/female, and so on (1990: 92-98). The notion of "normal" defined as "conforming to the common type" appeared in the English context around 1840, and with it appeared associated words like "norm", "normality" and "normalcy". The concept was linked to two essential nineteenth century concerns: eugenics and miscegenation.

Eugenics consisted in the improvement of a race through the practice of selective breeding, that is, the reproduction of the fittest members of society. The black and the freak were constructed as the "abnormal" and the "other", in contrast with the white British coloniser (Durbach 2010: 21-22). White colonial supremacy had to be preserved, hence the fear of miscegenation. Sarah herself discovers the meaning of this word when she is told that it was "marriage or fornication between a black person and a white person" (ChaseRiboud 2003: 209). The fear of miscegenation was not only about interracial sexuality itself, but about its consequences with the decline of the white population. The white man

\footnotetext{
6 According to Sarah's biographers, she travelled with Dunlop/Cesars to Paris, and it was there that her property changed hands in the figure of Reaux, who was very well connected and already belonged to the world of show business (Crais and Scully 2009: 112-130).
} 
had to control his sexuality and the sexuality of the "other", and the "other" was always represented by the racialised female. Both women and natives needed to be controlled by the European male, especially black females who were more "primitive" and sexually active (Gilman 1985: 237). Taxonomy and Taxidermy were also emerging disciplines concerned with the classification of human beings and with finding the "missing link" between man and animal, the same as Teratology and Teratogeny were concerned with the study of birth defects and physical anomalies. All this implied the flourishing of anatomy and natural history, and anthropological and criminal studies carried out by figures such as Buffon, Lombroso, Ferrero, De Blasio and Hildebrandt in the eighteenth century were very influential to establish the connection between racial inferiority and sexual degeneracy. The same association was established with female criminals, lesbians, nymphomaniacs and prostitutes (Heilmann \& Llewellyn 2010: 121). In particular, Buffon's application of the theory of the Great Chain of Being to blacks established that the Hottentot was the missing link between the human and the orangutan. His belief was that black people occupied the antithetical position in relation to the white on the scale of humanity, and this opposition found its counterpart in the difference between the normal and the pathological in the medical model (Gilman 1985: 212). In Sarah's own words, "I even wondered if their belief was more than half right -that I really mattered less than a camel, less than a dog, without a $n / u m$, that even my shape was not human according to civilised people", (Chase-Riboud 2003: 41) and she talks about her self as "the true, the only, missing link of evolution". Likewise her master announces her as "a true phenomenon of nature, the virgin Eve risen from the Garden of Creation to the first, primitive level of humanity" to the crowds come to see her (Chase-Riboud 2003: 105).

Female sexuality was understood as pathological in the nineteenth century and the polygenetic argument was the ideological basis for the dissection of these women. If the genitalia of black females were conspicuously different from the white norm, then that was sufficient proof that the black race was inferior to the European (Gilman 1985: 216). The oddities found in the Hottentot organs of generation were believed to be biological variations and not adaptations. The Venus sexuality was associated with the sexuality of lesbians and the idea of a congenital error. In fact, sometimes in the novel Sarah is accused of prostitution and lesbianism. In this sense, Havelock Ellis established a relationship between the genitalia as a primary sexual characteristic and the buttocks as a secondary one as symptoms of the primitive in black women in his Studies in the Psychology of Sex (1905). However, a connection was never established with the reproductive organs of the black male. He again ascertained the existence of a scale of beauty in the Great Chain of Being where black people were identified as the "sexualised other" and placed together with the ill, the bestial and the freak, following the Foucauldian tendency to classification of deviant elements in society (Gilman 1985: 218). Even Darwin agreed with this view and becomes one of those intertextual references in the novel, being presented as the author of On the Origin of Species (1859) -where a new theory was developed that man was not God's creation but evolved from inferior animals by a process of natural selection- and at the same time resembling an ape. In The Descent of Man (1875), Darwin alluded to steatopygia to point at the aesthetic differences between the black and white races, which had different notions of beauty. 
In this context, it is possible to understand the fascination that Cuvier felt for Sarah Baartman; he wanted to examine and sketch the Venus Hottentot for a period of three days. Georges Léopold Chrétien Cuvier was a prominent naturalist in Europe; he was the maximum authority at the National Museum of Natural History in Paris, which was located inside the Jardin des Plantes that comprised the botanical gardens and the zoo, presided by Etienne Geoffroy Saint-Hilaire. Cuvier and Saint-Hilaire together with Henri-Marie Ducrotay de Blainville were the intellectuals leading the scientific world of the nineteenth century in France and Europe. Cuvier was the Professional Chair of Comparative Anatomy at the Natural History Museum and the Chair of Natural History at the Collège de France as well as the Chancellor of the University of Paris and Councillor of State to the King at the time of the Venus Hottentot exhibition in Paris (Holmes 2007: 119-122). Nonetheless, she did not want to have her sex examined and she would cover it with a white handkerchief. All this process is connected with the idea of Scopophilia, which is concerned with the pleasure of looking. Sarah is subjected to the gaze of the scientific elite that was convinced of her racial inferiority and sub-humanity. She stood also as a life model for some artists, and in chapter 18 where her display in front of the scientific community is described, there is an essential figure, the sculptor Nicolas Tiedemann, who sees some humanity in Sarah. ${ }^{7}$ Both Blainville and Cuvier were obsessed with the examination of the Hottentot's genitalia and this obsession was an expression of pornographic scopophilia or scopopornia (Heilmann \& Llewellyn 2010: 127-128). During her inspection, both her genitalia and buttocks were the object of analysis, but everything was aimed at proving Negro inferiority and also woman's inferiority, establishing the differences through the size of the skulls. The fact that women's skulls were slightly smaller than those of men was attributed to their physical and intellectual inferiority. In Cuvier's own words, "Hottentots are Negroes even though their hyper-negroidness puts them at the bottom of this category and therefore at the absolute bottom of the Chain of Being, with the exception of idiots, lunatics and mixed bloods..." In the novel, he associates the Hottentot apron with "the natural degree of lasciviousness and voluptuousness" of the race, which demonstrates their primitiveness and deviant sexuality (Chase-Riboud 2003: 239-240). Cuvier positions himself as a naturalist describing Sarah's Hottentot apron in the following terms: "I contend that the apron is a morbid development of the inner vaginal lips, divided like two wrinkled, fleshy petals which, if raised, form the figure of a heart" (Chase-Riboud 2003: 242).

However, Sarah was very ill and depressed, and died of tuberculosis in January 1816 . Her death brought about her utmost vilification and her dissection. An autopsy was conducted and described by Henri de Blainville in 1816 first and by Cuvier later in 1817. In both cases, the main objectives were to compare a female Hottentot as the most inferior human being with the most developed ape, and to describe the aberration of her organs of generation (Gilman 1985: 213). In the dissection of her body, erotic connotations can be discerned that imply the public appropriation of the exotic body of the other, and for the first time her genitalia and her buttocks are opened up and shown to the world. These parts are described as "the

\footnotetext{
The character of Nicolas Tiedman is based on the real-life Nicolas Huet, who was a painter working for Cuvier that sketched Baartman's body, and the scientist Frederick Tiedemann who was an abolitionist and thought that the differences between blacks and whites was the result of slavery and the degrading way in which black people were treated (Heilmann \& LLwewellyn, 2010: 128).
} 
map of Africa". They also took a death mask and a mould of her body, and these together with her skeleton, brains and genitals were displayed in the Natural History Museum and then in the Museum of Man in Paris.

However, Chase-Riboud introduces an important element at the end of the novel giving some agency to Sarah through her spectral presence. Spectrality is another prominent feature of Neo-Victorian fiction and the Gothic genre. Spectral novels make a tribute to the dead, the voiceless and the marginalised, like black women who had a marginal status as "the other". Spectrality and the Gothic are closely connected with hauntology, a term that was coined by Jacques Derrida in his Spectres of Marx (1993). His ghosts are the object of literary enquiry, are neither present nor absent, and occupy the inbetweenness of "the other", so they can speak for the unmentionable and can also be a metaphor for a past of oppression and discrimination (Davies 2005: 373-374). Sarah takes revenge on all those members of the western civilisation and the scientific world who had abused and exploited her by haunting them to death. Her spirit flies free at last, but her mortal remains were still deprived of sepulture.

\section{CONCLUSION}

In the 1970's Sarah Baartman's bodily parts were taken out of view due to a series of protests by feminists and were removed to a storeroom. After long negotiations between the French and the South-African governments, her remains were repatriated to South Africa to be buried. The ceremony took place on August 8, 2002, when the National Women's Day was being celebrated. The country was freed from the Dutch, the English and the Afrikaner, and the age of the apartheid was over when the Venus Hottentot could finally rest in her homeland, close to the Gamtoos River.

As I have shown throughout the text, to distinguish between self and other was essential at the age of Imperialism, keeping the distance between ruler and ruled, and constructing hegemonic discourses based on bodily difference and bodily norms that regulated those colonial subjects which represented degeneracy and deviance. In the nineteenth century the Venus Hottentot became the embodiment of western anxieties about racial diversity, strengthening the binaries civilised/savage, modern/ancient, evolved/primitive, white/black and governing/governed. She was the victim of the objectification and commodification of the black female body, following the trend of the slave trade in the fetishization of the dark skin. She also became an icon of sexual depravity and ugliness in the white mind, making the story of black women's sexuality a silent one marked by oppression and discrimination. As we have seen, the scientific and the medical discourses of the nineteenth century also contributed to this classification of black people as the subaltern and the subhuman.

However, what Chase-Riboud tries to contend in her recreation of the Venus Hottentot's story is that what is imperative is to recover and to remember the individual behind the cultural icon, to give voice and agency to those people neglected and silenced by white history, and this is one of the main objectives of the Neo-Victorian fiction. In this sense, the word "rememory" is loaded with the traces and the remains of the past that this novel tries to recover because of their relevance to our present, still full with violence against black women. Although the history of ethnographic exhibition has been traditionally associated 
with the history of colonial conquest and enslavement and carries bodily inscriptions that link the female black body with notions of the grotesque and the obscene, Chase-Riboud and many other black writers and feminists claim the visibility and the beauty of this body through aesthetic resistance and subjectivity. She resorts to spectrality, another feature of Neo-Victorian fiction, to do justice to Sarah Baartman's life and death, and makes a joke on white civilisation by making it clear that those who had been considered as the missing link between man and animal are in fact more honest, law-abiding and civilised people.

\section{REFERENCES}

Chase-Riboud, B. 2003. The Hottentot Venus. New York: Anchor Books.

Crais, C. and Scully, P. 2009. Sarah Baartman and the Hottentot Venus: A Ghost Story and a Biography. Princeton and Oxford: Princeton University Press.

CurTis, D. 2004. "Commodities and Sexual Subjectivities: A Look at Capitalism and its Desires". Cultural Anthropology 19, 1: 95-121.

Davies, C. 2005. "Ét at Présent: Hauntology, Spectres and Phantoms". French Studies LIX, 3: 373-379.

Durbach, N. 2010. Spectacle of Deformity: Freak Shows and Modern British Culture. Berkeley and London: University of California Press.

Foucault, M. 1979 (1975). Discipline and Punish: The Birth of a Prison. Trans. Alan Sheridan. London: Penguin Books.

------ 1990 (1976). The History of Sexuality: Volume I, An Introduction. Trans. Robert Hurley. London: Penguin Books.

GiLman, S.L. 1985. "Black Bodies, White Bodies: Toward an Iconography of Female Sexuality in Late Nineteenth-Century Art, Medicine, and Literature". Critical Enquiry 12, 1: 204-242.

Heilmann, A. and Llewellyn, M. 2010. Neo-Victorianism: The Victorians in the Twenty-First Century, 1999-2009. London: Palgrave Macmillan.

-----. 2004. "Hystorical Fictions: Women (Re)Writing and (Re)Reading History". Women: A Cultural Review 15, 2: 137-152.

Henderson, M. G. 2003. "Josephine Baker and La Revue Negre: From Ethnography to Performance". Text and Performance Quarterly 23: 2, 1: 107-133.

-----. 2011. “About Face, or, What Is This 'Back' in B(1)ack Popular Culture?: From Venus Hottentot to Video Hottie". Cultural Migrations and Gendered Subjects: Colonial and Postcolonial Representations of the Female Body. Ed. S.P. CASTRO Borrego and M.I. Romero Ruiz. Newcastle-upon-Tyne: Cambridge Scholars Publishing. 125-156.

Hill Collins, P. 1991. Black Feminist Thought: Knowledge, Consciousness, and the Politics of Empowerment. London: Routledge. 
Hobson, J. 2005. Venus in the Dark: Blackness and Beauty in Popular Culture. London and New York: Routledge.

Holmes, R. 2007. The Hottentot Venus: The Life and Death of Saartjie Baartman: Born 1789-Buried 2002. London: Bloomsbury.

Hutcheon, L. 2002 (1989). The Politics of Postmodernism. London: Routledge.

Llewellyn, M. 2009. "Neo-Victorianism: On the Ethics and Aesthetics of Appropriation”. Lit: Literature, Interpretation, Theory 20, 1-2: 27-44.

Preston, P. 2008. "Victorianism in Recent Victorian Fiction". History, Politics, Identity: Reading Literature in a Changing World. Ed. KNEZEVIC, M. and NiKCEVICBatricevic, A. Newcastle-upon-Tyne: Cambridge Scholars Publishing. 91-109.

Smith McKoy, S. 2011. "Placing and Replacing 'The Venus Hottentot': An Archeology of Pornography, Race and Power". Representation and Black Womanhood: The Legacy of Sarah Baartman. Ed. Gordon-Chipembere, N. London: Palgrave Macmillan. 85-97.

SPILlers, H. J. 1987. “Mama’s Baby, Papa's Maybe: An American Grammar Book”. Diacritics XVII, 2: 64-81. 